\title{
Bibliography
}

\section{Archival sources}

\section{British Library}

Council of Women Civil Servants (Higher Grades), Statement Prepared for the Royal Commission on the Civil Service (1929-1930), October 1930.

Federation of Women Civil Servants, Women in the Civil Service: Grading - or De-Grading? Undated (1921)[?].

\section{British Postal Museum \& Archive (BPMA)}

POST 30 Series: Post Office: Registered Files, Minuted papers (England and Wales).

POST 33 Series: Post Office: Registered Files, Minuted papers (General).

POST 47 Series: Post Office: Army Postal Series.

POST 57 Series: Post Office: Staff Recruitment.

POST 82 Series: Post Office: Telegraphs, Post Office (Inland).

POST 92 Series: Post Office Publications.

POST 115 Series: Post Office: Staff Association and Union Publications.

POST 121 Series: Post Office: Registered Files, Minuted and Decentralised Registry Papers

(Miscellaneous Papers).

POST 122 Series: Post Office: Registered Files, Minuted and Decentralised Registry Papers

(Miscellaneous Papers).

\section{BT Archives}

POST 33 Series: Post Office: Registered Files, Minuted papers (General).

\section{Imperial War Museum Sound Archive}

IWMSA, 668, interview with Lilian Gertrude Wolfe, 27 February 1974.

IWMSA, 676, interview with Mrs Thomas, 1975.

IWMSA, 3151/1, interview with Mary Madden, 1977.

IWMSA, 8889/3, interview with Eileen Johnston, 1985.

\section{London Metropolitan Archives}

18.3 LCC Staff Examination Papers.

GLSA Records of the LCC Staff Association.

LCC Minutes.

LCC Establishment Committee Minutes. 
LCC General Purposes Committee Minutes.

LCC Staff Lists.

LCC/CL/ESTAB Clerk of the Council's department establishment papers.

\section{Modern Records Centre, University of Warwick}

MSS.148/PA Records of the Postal \& Telegraph Clerks' Association.

MSS.148/PF Records of the Postman's Federation.

MSS.148/UCW Records of the Union of Communication Workers [formerly the Union of Post Office Workers].

MSS.415 Records of the Civil and Public Services Union and its predecessors.

\section{The National Archives}

T1: Treasury Board Papers and In-Letters.

T162: Treasury: Establishments Department, Registered Files.

T 171: Chancellor of the Exchequer's Office: Budget and Finance Bill Papers.

T 215: Treasury: Establishment General Division: Registered Files (EG and 2EG Series).

LAB 2: Ministry of Labour and predecessors: correspondence.

\section{The Wellcome Library}

SA/MWF: Records of the medical Women's Federation.

\section{The Women's Library}

6APC: Records of the Association of Post Office Women Clerks.

6JCS: Records of the Joint Committee on Women in the Civil Service.

6EPC: Records of the Equal Pay Campaign Committee.

6NCS: Records of the National Association of Women Civil Servants.

\section{Online resources}

Oxford Dictionary of National Biography.

\section{Newspapers and periodicals}

British Medical Journal

Civil Service Argus

Clerical Grades Monthly

Daily Mail

Daily Mirror 
Local Government Service

London County Council Staff Association Gazette

London Town

Manchester Guardian

The Post

Red Tape

The Times

The Spectator

\section{Published reports and evidence}

Committee on Recruitment for the Civil Service After the War Final Report (HMSO, 1919). Hansard.

The Marriage Bar in the Civil Service, Report of the Civil Service National Whitley Council Committee (London: HMSO, 1946).

Report of the Civil Service National Whitley Council Reorganisation Committee (London: HMSO, 1920).

Report of the Royal Commission on the Civil Service (London: HMSO, 1931).

Report of the Royal Commission on Equal Pay (London: HMSO, 1946).

Report of the War Cabinet Committee on Women in Industry (London: HMSO, 1919).

Royal Commission on the Civil Service 1929-1931, Evidence, (London: HMSO, 1930).

Royal Commission on Equal Pay, Minutes of Evidence taken before the Royal Commission on Equal Pay (London: HMSO, 1945).

\section{Published primary sources}

Barton, Dorothea M., 'The Course of Women's Wages', Journal of the Royal Statistical Society, vol. 82, no. 4 (July 1919), pp.508-553.

Beauchamp, Joan, Women Who Work (London: Lawrence \& Wishart, 1937).

Bondfield, Margaret, A Life's Work (London: Hutchinson \& Co, 1949).

Bowley, Ruth, 'The Cost of Living of Girls Professionally Employed in the County of London', The Economic Journal, vol. 44, no. 174 (June 1934), pp.328-334.

Breckinridge, S.P., 'The Home Responsibilities of Women Workers and the "Equal Wage", The Journal of Political Economy, vol. 31, no. 4 (August 1923), pp.521-543.

Brittain, Vera, Women's Work in Modern England (London: Noel Douglas, 1928).

Brown, W. J., Civil Service Compendium (London: CSCA, 1927).

Burton, Elaine, What is She Worth? A Study on the Report on Equal Pay (London: Fitzroy Publications, 1947).

Cazalet-Keir, Thelma, From the Wings: An Auobiography (London: Bodley Head, 1967).

Council of Civil Service Unions, Equal Opportunities for Men and Women in the Civil Service (London: Council of Civil Service Unions, 1985).

Council of Women Civil Servants (Higher Grades), Higher Appointments Open to Women in the Civil Service (London: P. S. King and Son, Ltd., 1928). 
Council of Women Civil Servants (Higher Grades), Higher Appointments Open to Women in the Civil Service, 3rd edn (P. S. King and Son, Ltd, 1935).

Courtney, Janet, Recollected in Tranquillity (London: Heinemann, 1926).

Drake, Barbara, Women in Trade Unions (London: Virago, 1984, first published in 1920 by Labour Research Department).

Edgeworth, F. Y., 'Equal Pay to Men and Women for Equal Work', The Economic Journal, vol. 32, no. 128 (December 1922), pp.431-457.

Evans, D., Women and the Civil Service: A History of the Development of the Employment of Women in the Civil Service, and a Guide to Present-Day Opportunities (London: Pitman, 1934).

Fawcett, Millicent G., 'Equal Pay for Equal Work', The Economic Journal, vol. 28, no. 109 (March 1918), pp.1-6.

Fawcett, Millicent, What I Remember (London: Fisher Unwin Ltd, 1925).

Garland, Charles H., 'Women as Telegraphists', The Economic Journal, vol. 11, no. 42 (June 1901), pp.251-261.

Hinchy, F. S., So Much in Life (London and New York: Regency Press, 1971).

Hughes, D. W., Careers for Our Daughters (London: A \& C Dent, 1936).

Hutchins, B. L. (Fabian Women's Group), The Working Life of Women, Fabian Tract no. 157 (London: The Fabian Society, 1911).

Kemp-Jones, E. M., The Employment of Women in the Civil Service, Civil Service Department Management Studies 3 (Edinburgh: HMSO, 1971).

Martindale, Hilda, From One Generation to Another: 1839-1944: A Book of Memoirs (London: Allen \& Unwin, 1944).

Meynell, Alix, Public Servant, Private Woman (London: Victor Gollancz, 1988).

Morley, Edith (ed.), Women Workers in Seven Professions (London: Fabian Society, 1914).

Murray, G. E. P., The Post Office (London, 1927).

Rathbone, Eleanor, 'The Remuneration of Women's Services', The Economic Journal, vol. 27, no. 105 (March 1917), pp.55-68.

Scudamore, Frank, A Sheaf of Memories (London: Fisher Unwin Ltd, 1925).

Smith, E., Wage-Earning Women and their Dependents (London: The Fabian Society, 1915).

Society of Civil and Public Servants, Equality: The Next Step. The Changing Role of Women in the Civil Service (London: SCPS, 1982).

Stocks, Mary, My Commonplace Book: An Autobiography (Trowbridge and London: Redwood Press, Ltd, 1970).

Strachey, Ray, The Cause [1928] (London: Virago, 1979).

The Suffrage Annual and Women's Who's Who, 1913 (London: Stanley Paul and Co., 1913).

Summerskill, Edith, A Woman's World (London: Heinemann, 1967).

This is the Road: The Conservative and Unionist Party's Manifesto (1950).

Thompson, Flora, Lark Rise to Candleford [1945] (London: Penguin, 2000).

Webb, Beatrice, The Wages of Men and Women: Should They Be Equal? (London: Fabian Society, 1919).

Women and Work Commission, Shaping a Fairer Future (London: Department of Trade and Industry, 2006). 


\section{Secondary sources}

Adams Carole Elizabeth, 'White Blouse and White Collar: Work, Culture and Gender' Gender and History, vol. 2, issue 3 (September 1990), pp.343-348.

Alberti, Johanna, Beyond Suffrage: Feminists in War and Peace, 1914-1928 (London and Basingstoke: Macmillan, 1989).

Alexander, Sally, 'Bringing Women into Line with Men: The Women's Trade Union League, 1874-1921' in Sally Alexander (ed.), Becoming a Woman (London: Virago, 1994), pp.57-74.

Alexander, Sally, 'Men's Fears and Women's Work: Responses to Unemployment in London Between the Wars' Gender and History, vol. 12, no. 2 (July 2000), pp.401-425.

Anderson, Gregory, Victorian Clerks (Manchester: Manchester University Press, 1976).

Andrews, Maggie, The Acceptable Face of Feminism: The Women's Institute as a Social Movement (London: Lawrence \& Wishart, 1997).

Bagilhole, Barbara, Women, Work and Equal Opportunity: Underachievement in the Civil Service (Aldershot: Ashgate, 1994).

Bain, George, The Growth of White Collar Unionism (Oxford: Clarendon, 1970).

Baker, Maureen and Mary-Anne Robeson, 'Trade Union Reactions to Women Workers and Their Concerns' Canadian Journal of Sociology, vol. 6, no. 1 (Winter, 1981), pp.19-31. Banks, Olive, Faces of Feminism (London: Basil Blackwell, 1986).

Beaumont, Caitriona, 'Citizens not Feminists: The Boundary Negotiated between Citizenship and Feminism by Mainstream Women's Organisations in England, 1928-1939' Women's History Review, vol. 9, no. 2 (June 2000), pp.411-429.

Beaumont, Caitriona, 'The Women's Movement, Politics and Citizenship, 1918-1950s' in Ina Zweiniger-Bargielowska (ed.), Women in Twentieth Century Britain (Harlow: Pearson Education, 2001).

Beddoe, Deirdre, Back to Home and Duty: Women Between the Wars (London and San Francisco: Pandora Press, 1989).

Beechey, Veronica, Unequal Work (London: Verso, 1987).

Bennett, Robert, 'Gendering Cultures in Business and Labour History: Marriage Bars in Clerical Employment' in Margaret Walsh (ed.), Working Out Gender: Perspectives from Labour History (Aldershot: Ashgate, 1999).

Berry, Paul and Alan Bishop (eds), Testament of a Generation: The Journalism of Vera Brittain and Winifred Holtby (London: Virago, 1985).

Bingham, Adrian, Gender, Modernity, and the Popular Press in Inter-War Britain (Oxford: Oxford University Press, 2004).

Black, John, 'War, Women and Accounting: Female Staff in the UK Army Pay Department Offices, 1914-1920' Accounting, Business \& Financial History, vol. 16, no. 2 (July 2006), pp. 195-218.

Blackburn, Robert, Union Character and Social Class: A Study of White Collar Unionism (London: Batsford, 1967).

Boston, Sarah, Women Workers and the Trade Unions (London: Lawrence \& Wishart, 1987).

Boussahba-Bravard, Myriam (ed.), Suffrage Outside Suffragism (London: Palgrave, 2007).




Bradley, H., Men's Work, Women's Work (Cambridge: Polity Press, 1989).

Braithwaite, Brian, Noelle Walsh and Glyn Davies (eds), Ragtime to Wartime: The Best of Good Housekeeping, 1922-1939 (London: Leopard Books, 1995).

Braybon, Gail, Women Workers in the First World War (London and New York: Routledge, 1989).

Braybon, Gail and Penny Summerfield, Out of the Cage: Women's Experiences in Two World Wars (London and New York: Pandora Press, 1987).

Brimelow, E., 'Women in the Civil Service', Public Administration, vol. LIX (1981), pp.313-335.

Brookes, Pamela, Women at Westminster: An Account of Women in the British Parliament, 1918-1966 (London: Peter Davies, 1967).

Caine, Barbara, 'Feminism in London, circa 1850-1950' Journal of Urban History, vol. 27, no. 6 (September 2001), pp.765-778.

Campbell-Smith, Duncan, Masters of the Post (London: Penguin, 2011).

Chapman, Richard A., Leadership in the British Civil Service (London and Sydney: Croom Helm, 1984).

Chapman, Richard A., The Civil Service Commission, 1855-1991: A Bureau Biography (London: Routledge, 2004).

Clendinning, Anne, " "Deft Fingers" and "Persuasive Eloquence": The "Lady Demons" of the English Gas Industry, 1888-1918', Women's History Review, vol. 9, no. 3 (2000), pp.501-537.

Clifton, Gloria, 'Members and Officers of the LCC, 1889-1965' in Andrew Saint (ed.), Politics and the People of London: The London County Council, 1889-1965 (London and Roncevert: The Hambledon Press, 1989), pp.1-26.

Clifton, Gloria, Professionalism, Patronage and Public Service in Victorian London (London: The Athlone Press, 1992).

Clinton, Alan, Post Office Workers: A Trade Union and Social History (London and Boston: Allen \& Unwin, 1984).

Cohen, E. W., The Growth of the British Civil Service 1780-1939 (London: George Allen \& Unwin, 1941).

Cohn, Samuel, 'Clerical Labor Intensity and the Feminisation of Clerical Labor in Great Britain, 1857-1937' Social Forces, vol. 63, no. 4 (June 1985), pp.1060-1068.

Cohn, Samuel, The Process of Occupational Sex-Typing: The Feminisation of Clerical Labour in Great Britain (Philadelphia: Temple University Press, 1985).

Cole, Margaret (ed.), The Road to Success: Twenty Essays on the Choice of a Career for Women (London: Methuen \& Co., 1936).

Copelman, Dina, London's Women Teachers: Gender, Class and Feminism 1870-1930 (London and New York: Routledge, 1996).

Cowman, Krista and Louise Jackson (eds), Women and Work Culture: Britain c. 1850-1950 (Aldershot: Ashgate, 2005).

Crawford, Elizabeth, The Women's Suffrage Movement: A Reference Guide, 1866-1928 (Abingdon: Routledge, 2001).

Cretney, Stephen, Family Law in the Twentieth Century (Oxford: Oxford University Press, 2003). 
Crompton, Rosemary and Kay Sanderson, Gendered Jobs and Social Change (London: Unwin Hyman, 1990).

Dale, H. E., The Higher Civil Service of Great Britain (Oxford: Oxford University Press, 1941).

Daunton, Martin, Royal Mail: The Post Office Since 1840 (London and Dover, NH: Athlone Press, 1985).

Davies, Celia, 'The Health Visitor as Mother's Friend: A Woman's Place in Public Health, 1900-1914' Journal of the Social History of Medicine, vol. 1, no. 1 (1988), pp.39-59.

Davin, Anna, 'City Girls: Young Women, New Employment, and the City, London, 1880-1910' in Mary Jo Maynes, Birgitte Soland and Christina Benninghaus (eds), Secret Gardens, Satanic Mills: Placing Girls in European History, 1750-1960 (Bloomington: Indiana University Press, 2005), pp.209-223.

Dohrn, Susanne, 'Pioneers in a Dead-End Profession: The First Women Clerks in Banks and Insurance Companies' in Gregory Anderson (ed.), The White-Blouse Revolution: Female Office Workers since 1870 (Manchester: Manchester University Press, 1988), pp.48-66.

Dorfman, Gerald A., Wage Politics in Britain, 1945-1967 (London: Charles Knight \& Co., 1974).

Durham, John, Telegraphs in Victorian London (Cambridge: The Golden Head Press, 1959).

Dyhouse, Carol, No Distinction of Sex? Women in British Universities, 1870-1939 (Oxford: Routledge, 1995).

Dyhouse, Carol, Students: A Gendered History (Oxford: Routledge, 2006).

Dyhouse, Carol, 'Women Students and the London Medical Schools, 1914-1939: The Anatomy of a Masculine Culture' Gender and History, vol. 10, issue 1 (1998), pp.110-132.

Fisher, Kate, Birth Control, Sex and Marriage in Britain, 1918-1960 (Oxford: Oxford University Press, 2008).

Forrest, Colleen Margaret, 'Familial Poverty, Family Allowances, and the Normative Family Structure in Britain, 1917-1945, Journal of Family History, vol. 26, no. 4 (2001), pp.508-528.

Gamarnikow, Eva, Morgan, David, Purvis, June and Taylorson, Daphne (eds), Gender, Class and Work (London: Heinemann, 1983).

Geddes, J. F., 'The Doctors' Dilemma: Medical Women and the British Suffrage Movement' Women's History Review, vol. 18, no. 2 (April 2009), pp.203-218.

Gibbon, Gwilym and Reginald W. Bell, History of the London County Council, 1889-1939 (London: Macmillan \& Co., 1939).

Gladden, E. N., Civil Service Staff Relationships (London: William Hodge and Company, 1943).

Gladden, E. N. Civil Service or Bureaucracy? (London: Staples Press Ltd, 1956).

Glucksmann, Miriam, Women Assemble: Women Workers and the New Industries in Inter-War Britain (Routledge: London, 1990).

Godwin, Anne, 'Early Years in the Trade Unions' in Lucy Middleton (ed.), Women in the Labour Movement (London: Croom Helm, 1977), pp.94-112.

Grant, Linda, 'Women's Work and Trade Unionism in Liverpool, 1890-1914' North West Labour History Society Bulletin, no. 7 (1980-1981), pp.65-83.




Graves, Pamela M., Labour Women: Women in British Working-Class Politics, 1918-1939 (Cambridge: Cambridge University Press, 1994).

Grint, Keith, 'Women and Equality: The Acquisition of Equal Pay in the Post Office, 1870-1961' Sociology, vol. 22, no. 1 (1988), pp.87-108.

Halsey, A. H., British Social Trends Since 1900 (Basingstoke and London: Macmillan, 1988). Harrison, Brian, 'Women in a Men's House: The Women M.P.s, 1919-1945' The Historical Journal, vol. 29, no. 3 (September 1986), pp.623-654.

Harrison, Brian, 'Class and Gender in Modern British Labour History' Past and Present, no. 124 (August 1989), pp.121-158.

Hede, Andrew, 'Women Managers in the Civil Service: The Long Road towards Equity in Britain' International Review of Administrative Sciences, vol. 61, no. 4 (1995), pp.587-600.

Hennessy, Peter, Having It So Good: Britain in the Fifties (London: Penguin, 2007).

Heritage, John, 'Feminisation and Unionisation: A Case Study from Banking' in Eva Gamarnikow, David Morgan, June Purvis and Daphne Taylorson (eds.), Gender, Class and Work (London: Heinemann, 1983), pp.131-148.

Hinton, James, Women, Social Leadership, and the Second World War (Oxford: Oxford University Press, 2002).

Holcombe, Lee, Victorian Ladies at Work: Middle-Class Working Women in England and Wales, 1850-1914 (Newton Abbot: David \& Charles, 1973).

Holden, Katherine, 'Imaginary Widows: Spinsters, Marriage and the "Lost Generation" in Britain after the Great War' Journal of Family History, vol. 30, no. 4 (2005), pp.387-412.

Holden, Katherine, The Shadow of Marriage (Manchester: Manchester University Press, 2007).

Hollis, Patricia, Ladies Elect: Women in English Local Government, 1865-1914 (Oxford: Oxford University Press, 1986).

Holtzmann, Ellen, 'The Pursuit of Married Love: Women's Attitudes Towards Sexuality and Marriage in Great Britain, 1918-1939' Journal of Social History, vol. 16 (1982), pp.39-52.

Humphries, B. V., Clerical Unions in the Civil Service (Oxford: Oxford University Press, 1958). Imlay Buckley, Elizabeth and Dorothy Usher Potter (eds), Ida and the Eye: A Woman in British Ophthalmology: From the Autobiography of Ida Mann (Tunbridge Wells: Parapress Ltd, 1996).

Jackson, Louise A., Women Police (Manchester: Manchester University Press, 2006). Jeffrey, Keith, The GPO and the Easter Uprising (Dublin: Irish Academic Press Ltd, 2006). Jeffreys, Sheila, The Spinster and Her Enemies: Feminism and Sexuality, 1880-1930 (London: Pandora, 1985).

Jenkins, Sarah, Miguel Martinez Lucio and Mike Noon, 'Return to Gender: An Analysis of Women's Disadvantage in Postal Work' Gender, Work and Organisation, vol. 9, no. 1 (January 2002), pp.81-104.

Jones, Helen, Women in British Public Life, 1914-50: Gender, Power and Social Policy (Harlow: Pearson Education, 2000).

Jordan, Ellen, 'The Lady Clerks at the Prudential: The Beginning of Vertical Segregation by Sex in Clerical Work in Nineteenth Century Britain' Gender and History, vol. 8, no. 1 (April 1996), pp.65-81.

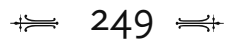


Jordan, Ellen, “"The Great Principle of English Fair Play": Male Champions, the English Women's Movement and the Admission of Women to the Pharmaceutical Society in 1879' Women's History Review, vol. 7, no. 3 (1998), pp.381-410.

Jordan, Ellen, The Women's Movement and Women's Employment in Nineteenth Century Britain (London and New York: Routledge, 1999).

Kean, Hilda, The Lives of Suffragette Teachers (London: Pluto Pres, 1990).

Kean, Hilda and Alison Oram, "Men must be educated and Women must do it"': The National Federation (later Union) of Women Teachers and Contemporary Feminism, 1910-30', Gender and Education, vol. 2, no. 2 (1990), pp.147-168.

Kelsall, R. K., Higher Civil Servants in Britain: From 1870 to the Present Day (London: Routledge and Kegan Paul Ltd, 1955).

Kemp-Jones, E. M., The Employment of Women in the Civil Service, Civil Service Department Management Studies 3 (HMSO: Edinburgh, 1971).

King, Sarah, 'Feminists in Teaching: The National Union of Women Teachers 1920-1945' in Martin Lawn and Gerald Grace (eds.), Teachers: The Culture of Politics and Work (Falmer Press: Lewes, 1987), pp.31-49.

Kingsley Kent, Susan, Making Peace: The Reconstruction of Gender in Interwar Britain (Princeton: Princeton University Press, 1993).

Klingender, Francis D., The Condition of Clerical Labour in Britain (London: Martin Lawrence, 1935).

Land, Hilary, 'The Family Wage' Feminist Review, no. 6 (1980), pp.55-77.

Langhamer, Claire, Women's Leisure in England, 1920-1960 (Manchester: Manchester University Press, 2000).

Law, Cheryl, Suffrage and Power: The Women's Movement, 1918-1928 (London: I. B. Tauris, 1997).

Law, Cheryl, Women: A Modern Political Dictionary (London: I. B. Tauris, 2000).

Laybourn, Keith, Unemployment and Employment Policies Concerning Women in Britain, 1900-1951 (Lewiston: The Edwin Mellen Press, 2002).

Leopold, E., In the Service of London: The Origin and Development of Council Employment from 1889 (London: Greater London Council, 1986).

Levine, Philippa, "Walking the Streets in a Way No Decent Woman Should": Women Police in World War I’ Journal of Modern History, vol. 66, no. 1 (March 1994), pp.34-78.

Lewenhak, S., Women and Trade Unions (London and Tonbridge: Ernest Benn, 1977).

Lewis, Jane, 'In Search of Real Equality: Women Between the Wars' in Frank Gloversmith (ed.), Class, Culture and Social Change: A New View of the 1930s (Sussex: Harvester Press, 1980), pp.208-239.

Lewis, Jane, Women in England, 1870-1950: Sexual Divisions and Social Change (Sussex: Wheatsheaf Books, 1984).

Lewis, Jane E., 'Women Clerical Workers in the Late Nineteenth and Early Twentieth Centuries', in Gregory Anderson (ed.), The White-Blouse Revolution: Female Office Workers since 1870 (Manchester: Manchester University Press, 1988), pp.27-47.

Lewis, Jane, Women and Social Action in Late Victorian and Edwardian Britain (Cheltenham: Edward Elgar, 1991).

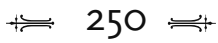


Littlewood, M., 'Makers of Men: The Anti-Feminist Backlash of the National Association of Schoolmasters in the 1920s and 1930s' Trouble and Strife, vol. 5 (1985), pp.22-30.

Livesey, Ruth, 'The Politics of Work: Feminism, Professionalization and Women Inspectors of Factories and Workshops', Women's History Review, vol. 13, no. 2 (2004), pp.233-262.

Lockwood, David, The Blackcoated Worker: A Study in Class Consciousness (London: Allen \& Unwin, 1958).

Logan, Anne, 'In Search of Equal Citizenship: The Campaign for Women Magistrates in England and Wales, 1910-1939', Women's History Review, vol. 16, no. 4 (September 2007), pp.501-518.

Logan, Anne, "Building a New and Better Order"? Women and Jury Service in England and Wales, 1920-1970', Women's History Review, vol. 22, no. 5 (2013), pp.701-716.

MacEwen Scott, Alison (ed.), Gender Segregation and Social Change: Men and Women in Changing Labour Markets (Oxford: Oxford University Press, 1994).

Macnicol, J., The Movement for Family Allowances, 1918-45 (London: Heinemann, 1980).

Marshall, C. F. D., The British Post Office from its Beginning to the End of 1925 (London: Humphrey Milford, 1926).

Martin, Jane, Women and the Politics of Schooling (London: Cassell, 1999).

Martin, Nancy, The Post Office: From Carrier Pigeon to Confravision (London: J. M. Dent and Sons Ltd, 1969).

Martindale, Hilda, Women Servants of the State, 1870-1938: A History of Women in the Civil Service (London: Allen \& Unwin, 1938).

Marwick, Arthur, The Deluge (Basingstoke: Macmillan, 1991).

McCarthy, Helen, 'Petticoat Diplomacy: The Admission of Women to the British Foreign Service, c.1919-1946' Twentieth Century British History, vol. 20, no. 3 (2009), pp.285-321.

McCarthy, Helen, Women of the World: The Rise of the Female Diplomat (London: Bloomsbury, 2014).

McClair, Elizabeth, 'Single Parenthood and the Civil Service' in Sybil Oldfield (ed.), This Working Day World: Women's Lives and Culture(s) in Britain, 1914-1945 (London: Taylor \& Francis, 1994), pp.68-72.

McGregor, O. R., Divorce in England: A Centenary Study (London, Heinemann: 1957).

Michaelsen, Kaarin, "'Union is Strength”: The Medical Women's Federation and the Politics of Professionalism, 1917-30' in Krista Cowman and Louise Jackson (eds), Women and Work Culture: Britain c.1850-1950 (Aldershot: Ashgate, 2005), pp.161-176.

Moran, Michael, The Union of Post Office Workers: A Study in Political Sociology (Basingstoke and London: Macmillan, 1974).

Mortimer, James E. and Valerie A. Ellis, A Professional Union: The Evolution of the Institution of Professional Civil Servants (London: George Allen \& Unwin, 1980).

Newman, Bernard, Yours For Action (London: Herbert Jenkins, 1953).

Nicholson, Virginia, Singled Out (London: Penguin, 2007).

Noakes, Lucy, Women in the British Army: War and the Gentle Sex, 1907-1948 (London: Routledge, 2006).

Oldfield, Sybil (ed.), This Working-Day World: Women's Lives and Cultures in Britain, 1914-1945 (London: Taylor \& Francis, 1994).




Oram, Alison, Women Teachers and Feminist Politics, 1900-39 (Manchester: Manchester University Press, 1996).

Parris, Henry, Staff Relations in the Civil Service: Fifty Years of Whitleyism (London: George Allen \& Unwin, 1973).

Pedersen, Susan, 'Gender, Welfare and Citizenship in Britain during the Great War', The American Historical Review, vol. 95, no. 4 (October 1990), pp.983-1006.

Pedersen, Susan, Eleanor Rathbone and the Politics of Conscience (New Haven and London: Yale University Press, 2004).

Pelling, Henry, A History of British Trade Unionism, 4th edn (Middlesex: Penguin, 1987).

Pennybacker, Susan, A Vision for London: Labour, Everyday Life and the LCC Experiment (London: Routledge, 1995).

Perriton, Linda, 'Forgotten Feminists: the Federation of British Professional and Business Women, 1933-1969' Women's History Review, vol. 16, issue 1 (2007), pp.79-97.

Pimlott, Ben (ed.), The Political Diary of Hugh Dalton, 1918-1940, 1945-1960 (London: Jonathan Cape, Ltd/LSE, 1986).

Potter, Allen, 'The Equal Pay Campaign Committee: A Case-Study of Pressure Group' Political Studies, vol. 5, no. 1 (1957), pp.49-64.

Pugh, Martin, Women and the Women's Movement in Britain, 1914-1959 (London: Macmillan, 1992).

Pugh, Martin, The Making of Modern British Politics: 1867-1945, 3rd edn (Oxford: Blackwell, 2002).

Pugh, Martin, We Danced All Night: A Social History of Britain Between the Wars (London: Vintage, 2009).

Pursell, Carroll, “Am I a Lady or an Engineer?" The Origins of the Women's Engineering Society in Britain, 1918-1940’ Technology and Culture, vol. 34, no. 1 (January 1993), pp.78-97.

Purvis, June, 'Jill Craigie (1914-1999)' Women's History Review, vol. 9, no. 1 (2000), pp.5-8. Redmayne, Sharon, 'The Matrimonial Causes Act, 1937: A Lesson in the Art of Compromise' Oxford Journal of Legal Studies, vol. 13, no. 2 (1993), pp.183-200.

Roberts, E., Women's Work 1840-1940 (Basingstoke and London: Macmillan, 1988).

Robinson, Howard, Britain's Post Office: A History of Development from the Beginnings to the Present Day (Oxford: Oxford University Press, 1953).

Rollyson, Carl, To Be A Woman: The Life of Jill Craigie (London: Aurum Press, Ltd, 2005).

Routh, Guy, 'Civil Service Pay, 1875 to 1950' Economica, vol. 21, no. 83 (August 1954), pp.201-223.

Sanderson, K., “'A Pension to Look Forward To....?": Women Civil Service Clerks in London, 1925-1939' in L. Davidoff and B. Westover (eds), Our Work, Our Lives, Our Words: Women's History and Women's Work (Basingstoke: Macmillan Education, 1986), pp.145-160.

Savage, Gail L., 'Social Class and Social Policy: The Civil Service and Secondary Education in England during the Interwar Period' Journal of Contemporary History, vol. 18, no. 2 (April 1983), pp.261-280.

Savage, Gail, The Social Construction of Expertise: The English Civil Service and Its Influence, 1919-1939 (Pittsburgh: Pittsburgh University Press, 1996).

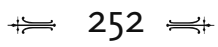


Savage, Gail, 'Erotic Stories and Public Decency: Newspaper Reporting of Divorce Proceeedings in England' The Historical Journal, vol. 41, no. 2 (June 1998), pp.511-528. Savage, M., 'Trade Unionism, Sex Segregation and the State: Women's Employment in "New Industries" in Inter-War Britain' Social History, vol. 13, no. 2 (1988), pp.209-230.

Savage, M., 'Gender and Career Mobility in Banking, 1880-1940' in A. Miles and D. Vincent (eds), Building European Society (Manchester: Manchester University Press, 1993), pp.196-216.

Savage M. and A. Witz (eds), Gender and Bureaucracy (Oxford: Blackwell, 1994).

Shapiro Sanders, Lise, Consuming Fantasies: Labour, Leisure and the London Shopgirl, 1880-1920 (Columbus: Ohio State University Press, 2006).

Siltanen, J., Locating Gender: Occupational Segregation Wages and Domestic Responsibilities (London: UCL Press, 1994).

Silverstone, Rosalie, 'Office Work for Women: An Historical Review' Business History, vol. 18 (1976), pp.98-110.

Smith, Harold, 'The Issue of "Equal Pay for Equal Work” in Great Britain 1914-19' Societas, vol. 8, no. 1 (1978), pp.39-51.

Smith, Harold, 'The Problem of "Equal Pay for Equal Work" in Great Britain during World War II' The Journal of Modern History, vol. 53, no. 4 (December 1981), pp.652-672.

Smith, Harold L., 'Sex versus Class: British Feminists and the Labour Movement 1919-1929' The Historian, vol. 47 (1984), pp.19-37.

Smith, Harold L. (ed.), British Feminism in the Twentieth Century (Aldershot: Edward Elgar, 1990).

Smith, Harold L., 'The Politics of Conservative Reform: The Equal Pay for Equal Work Issue, 1945-1955' The Historical Journal, vol. 35, no. 2 (June 1992), pp.401-415.

Smith, Harold L. 'Gender and the Welfare State: The 1940 Old Age and Widows' Pensions Act' History: The Journal of the Historical Association, vol. 80, no. 260 (1995), pp.382-399.

Smith, Harold L., 'British Feminism and the Equal Pay Issue in the 1930s', Women's History Review, vol. 5, no. 1 (1996), pp.97-110.

Solden, Norbert C., Women in British Trade Unions 1874-1976 (Dublin: Gill and Macmillan, 1978).

Sommerlad, H. and P. Sanderson, Gender, Choice and Commitment: Women Solicitors in England and Wales and the Struggle for Equal Status (Aldershot: Ashgate, 1998).

Spoor, Alec, White Collar Union: Fifty Years of NALGO (London: Heinemann, 1967).

Stack, Frieda, 'Civil Service Associations and the Whitley Report of 1917’ Political Quarterly, vol. 40, no. 3 (1969), pp.283-295.

Stone, Lawrence, Road to Divorce: England, 1530-1987 (Oxford: Oxford University Press, 1990).

Summerfield, Penny, Women Workers in the Second World War: Production and Patriarchy in Conflict (London: Routledge, 1989).

Summerfield, Penny, 'My Dress for an Army Uniform: Gender Instabilities in the Two World Wars', Inaugural Lecture (Lancaster: Lancaster University, 1997).

Summerfield, Penny and Corinna Peniston-Bird, Contesting Home Defence (Manchester: Manchester University Press, 2007).

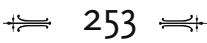


Thane, Pat, 'The Women of the British Labour Party and Feminism, 1906-1945' in H. L. Smith (ed.), British Feminism in the Twentieth Century (Aldershot: Ashgate, 1990), pp.124-143.

Thane, Pat, 'Women's History and Labour History' Labour History Review, vol. 55, no. 3 (Winter 1990), pp.14-16.

Thane, Pat, Foundations of the Welfare State, 2nd edn (Harlow: Longman, 1996).

Thane, Pat, 'What Difference did the Vote Make? Women in Public and Private Life in Britain since 1918, Historical Research, vol. lxxvi (2003), pp.268-285.

Theakston, Kevin, 'Evelyn Sharp (1903-1985)', Contemporary Record, vol. 7, no. 1 (1993), pp.132-148.

Thom, Deborah, Nice Girls and Rude Girls: Women Workers in World War I (London: I. B. Tauris, 2000).

Todd, Selina, “Boisterous Workers”: Young Women, Industrial Rationalisation and Workplace Militancy in Interwar England' Labour History Review, vol. 68, no. 3 (December 2003), pp.293-310.

Todd, Selina, Young Women, Work and the Family, 1918-1950 (Oxford: Oxford University Press, 2005).

Todd, Selina, 'Domestic Servants and Social Relations in England, 1900-1950' Past and Present, vols 2-3, no. 1 (2009), pp.181-204.

Vallance, Elizabeth, Women in the House (London: Continuum, 1979).

Vicinus, Martha, Independent Women: Work and Community for Single Women, 1850-1920 (London: Virago, 1985).

Verdon, Nicola, 'Agricultural Labour and the Contested Nature of Women's Work in Interwar England and Wales' Historical Journal, vol. 52, no. 1 (March 2009), pp.109-130.

Walby, Sylvia, Patriarchy at Work (Cambridge: Polity Press, 1986).

Weeks, Jeffrey, Sex, Politics and Society: The Regulation of Sexuality since 1800 (London: Longman, 1981).

Whitehead, Kay, 'Concerning Images of Women in Government Offices in the Early Twentieth Century: What Difference Does Age Make?' Australian Historical Studies, vol. 37, no. 127 (2006), pp.25-42.

Wigham, E., From Humble Petition to Militant Action: A History of the Civil and Public Services Association (London: Civil \& Public Services Association, 1980).

Williams, Philip M., Hugh Gaitskell (Oxford and New York: Oxford University Press, 1982).

Wilson, R. Guerriero, 'Women's Work in Offices and the Preservation of Men's "Breadwinning" Jobs in Early Twentieth-Century Glasgow', Women's History Review, vol. 10, issue 3 (2001), pp.463-482.

Witz, Anne, Professions and Patriarchy (London: Routledge, 1992).

Wojtczak, Helena, Railwaywomen: Exploitation, Betrayal and Triumph in the Workplace (Hastings: The Hastings Press, 2005).

Woodward, Nicholas, The Management of the British Economy, 1945-2001 (Manchester: Manchester University Press, 2004). 
Zimmeck, Meta, 'Strategies and Stratagems for the Employment of Women in the British Civil Service, 1919-1939', The Historical Journal, vol. 27, no. 4 (1984), pp.901-924.

Zimmeck, Meta, 'Jobs for the Girls: The Expansion of Clerical Work for Women, 1850-1914' in Angela V. John (ed.), Unequal Opportunities: Women's Employment in England, 1800-1918 (Oxford and New York: Basil Blackwell, 1986), pp.153-177.

Zimmeck, Meta, "Get Out and Get Under": The Impact of Demobilisation on the Civil Service, 1918-1932' in G. Anderson (ed.), The White-Blouse Revolution: Female Office Workers since 1870 (Manchester: Manchester University Press, 1988), pp.88-120.

Zimmeck, Meta, 'The New Woman in the Machinery of Government: A Spanner in the Works?' in R. Macleod (ed.), Government and Expertise in Britain, 1815-1919: Specialists, Administrators and Professionals (Cambridge: Cambridge University Press, 1988), pp.185-202.

Zimmeck, Meta, 'Marry in Haste, Repent at Leisure: Women, Bureaucracy and the Post Office, 1870-1920' in Mike Savage and Anne Witz (eds) Gender and Bureaucracy (Oxford and Cambridge, MA: Blackwell Publishers, 1992), pp.65-93.

Zimmeck, Meta, “"The Mysteries of the Typewriter": Technology and Gender in the British Civil Service, 1870-1914' in Gertjan de Groot and Marlon Schrover (eds), Women Workers and Technological Change in Europe in the Nineteenth and Twentieth Centuries (London: Taylor \& Francis, 1995), pp.67-96.

Zweiniger-Bargielowska, Ina (ed.), Women in Twentieth Century Britain (Harlow: Pearson Education, 2001).

\section{Theses}

Crowley, Mark, 'Women Workers in the Post Office, 1939-1945: Gender Conflict or Political Emancipation?' (unpublished PhD thesis, University of London, 2010).

Glew, Helen, 'Women's Employment in the General Post Office, 1914-1939' (unpublished $\mathrm{PhD}$ thesis, University of London, 2010).

Murphy, Catherine, "'On an Equal Footing with Men?": Women and Work at the BBC, 1923-1939' (unpublished PhD thesis, Goldsmiths, University of London, 2011).

Takayanagi, Mari, 'Parliament and Women, c.1900-1945' (unpublished PhD thesis, King's College, London, 2012).

\section{Online sources}

Fawcett Society, 'The Pay Gap By Occupation and Region', available at www.fawcettsociety. org.uk/index.asp?PageID=321, accessed 29 September 2009.

Fawcett Society, What about Women? (2013), available at www.fawcettsociety.org.uk/ wp-content/uploads/2013/02/Fawcett-Society-What-About-Women-report-low-res. pdf, accessed 13 August 2014.

'Fewer Women Getting Senior Civil Service Jobs', Guardian, 15 July 2008, available at www. guardian.co.uk/politics/2008/jul/15/whitehall-women, accessed 27 August 2009.

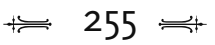


The Guardian, 'MOD needs to put women in senior positions, says top civil servant', 2 December 2011, available at www.guardian.co.uk/uk/2011/dec/02/mod-needswomen-senior-positions, accessed 2 December 2011.

House of Commons Library, Parliamentary Briefing papers, Civil Service Statistics (2013), p.7, available at www.parliament.uk/briefing-papers/SN02224.pdf, accessed 13 August 2014.

Office of National Statistics, Annual Survey of Hours and Earnings (2013), available at www.ons.gov.uk/ons/dcp171778_335027.pdf, accessed 13 August 2014.

Royal Mail Annual Report for year ended 29 March 2009, p.63. Available at ftp://ftp.royalmail.com/Downloads/public/ctf/rmg/200809RM_Group_Accounts_May_2009.pdf, accessed 1 September 2009.

'Women Graduates Step Off Fast Track for Civil Service', The Times, 20 June 2005, available at www.timesonline.co.uk/tol/life_and_style/education/student/news/article535357. exe, accessed 27 August 2009.

'Women "Still Fail Promotion Race": Figures Show Men's Firm Grip on Top Posts', Independent, 17 October 1994, available at www.independent.co.uk/news/uk/women-s till-fail-promotion-race-figures-show-mens-firm-grip-on-top-posts-1443387.html, accessed 27 August 2009.

\section{Film}

To Be A Woman, dir. by Jill Craigie (Outlook Films, 1951). 